\title{
Integrovaná tělesná výchova - limity a návrhy jejich řešení
}

\section{Integrated Physical Education - limits and proposals for their solution}

\author{
Radka Bartoňová, Ondřej Ješina \\ Fakulta tělesné kultury, Univerzita Palackého v Olomouci, \\ Česká republika
}

\section{Abstrakt:}

Integrace žáků se zdravotním postižením (ZdP) do hlavního vzdělávacího proudu se stává realitou na radě škol hlavního vzdělávacího proudu. Úspěšnost však může být velmi proměnlivá. Většina predmětů probihá za podpory speciálně pedagogických center. Integrace do tělesné výchovy (TV) bohužel bývá často opomíjená. V̌̌eobecně dochází často $k$ uvolñováni žáků se ZdP z TV. Nejčastější př́činami jsou bariérovost (nikoliv však pouze architektonická), obavy rodičü, nedostatečná kompetentnost pedagogů, nedostatek materiálního vybaveni aj. Správně vedená TV na školách může výrazně dopomoci k formování pozitivnich mezilidských vztahü, rozvíji řadu sociálnich dovedností, sebevědomí, komunikativni dovednosti, spolupodili se na úspěšné ontogenezi psychomotorických funkcí. Interakce s žákem se ZdP umožňuje rozvoj pozitivních vlastností $i$ u žáků intaktních. V př́spěvku uvádíme vybrané vnímané limity integrované TV a nabizime řšení na základě zkušeností při řešení projektů Centra APA, FTK UP v Olomouci.

\section{Abstract:}

Integration of students with disabilities (DD) in mainstream education is becoming a reality in a number of mainstream schools. Howe- 
ver, the success can be very variable. Most of the school subjects are supported by special educational needs advice centres. Unfortunately, integration in Physical Education (PE) is very often overlooked. In general, disabled children are often released from PE. The most common reasons are barriers (not only architectural), concerns of parents, lack of teachers' competence, lack of equipment, etc. Properly conducted Physical Education can significantly help to form positive interpersonal relationships, develop a range of social skills, self-confidence, and communication skills. It can also help to participate in successful ontogenesis psychomotor functions. Furthermore, interaction with disabled students can help intact students to develop positive qualities. In this paper, we present selected perceived limits of integrated PE and offer solutions based on experience in dealing with projects of the APA Centre, FTK UP in Olomouc.

Klíčová slova: integrace, tělesná výchova, žáci se zdravotním postižením, speciálně pedagogická centra.

Key words: Integration, physical education, students with disabilities, special education centres.

\section{ÚVOD}

V současné době pracuje české školství stále častěji v heterogenním prostředí. Legislativa umožňuje integraci dětí, žáků a studentů (dále jen žáků) se speciálními vzdělávacími potřebami (dále jen SVP) (Ješina, Kudláček et al., 2011). To může představovat pro pedagoga větší nároky a klást před něj nové. Jak uvádějí Kudláček, Ješina a Štěrbová (2008), do roku 1991 byla většina žáků se SVP vzdělávána ve speciálních segregovaných školách. Mezi lety 1991 až 2004 se integrace realizovala na základě metodických předpisů MŠMT. V roce 2004 integraci podpořil nový školský zákon, který byl v roce 2005 doplněn vyhláškou 73/2005 Sb., o vzdělávání dětí a žáků se speciálními vzdělávacími po- 
třebami a dětí a žáků mimořádně nadaných, ve znění pozdějších změn a předpisů. Dle tohoto zákona (561/2004 Sb., § 16) jsou za žáky se SVP považováni žáci se zdravotním postižením (tělesným, mentálním, zrakovým a sluchovým postižením, dále pak žáci s poruchou autistického spektra, s narušenou komunikační schopností, se specifickými poruchami učení nebo chování, se souběžným postižením více vadami), se zdravotním a sociálním znevýhodněním.

V souladu s platnou legislativou ČR se užívá v kontextu tělesné výchovy (TV) termín ,individuální integrace“. Termín ,integrace v TV“ znamená zařazení různých typů jedinců do společných forem TV. Tato forma integrace je založena na filozofii, že žáci by měli být vzděláváni a vychováváni společně $\mathrm{v}$ jedné třídě. Učitel tak obecně musí učinit nezbytná opatření v pedagogice, didaktice a osnovách, aby všichni žáci mohli dosáhnout cílů TV (Kudláček, 2008).

\section{HLAVNÍ ČÁST}

Navzdory mnoha pozitivních př́nosů integrace je nutné si uvědomit, že tzv. „úplná“ integrace není vždy optimálním řešením (Kudláček, 2008). Při začleňování žáků se SVP bychom měli vycházet $\mathrm{z}$ filosofie tzv. Least Restrictive Enviroment (prostředí, které žáka minimálně omezuje v naplnění jeho životního potenciálu). Ze zkušeností s integrací v zahraničí a i ze zkušeností z integrací u nás můžeme konstatovat, že integrace žáků je možná. Je však nezbytné respektovat určité zásady, které sebou integrace do TV přináší: aktivity musejí být pro všechny žáky bezpečné; aktivity musejí být smysluplné; ne každá aktivita je vhodná pro všechny; žáci nesmějí trpět pocitem ochuzení z důvodu integrace žáka se SVP (Kudláček \& Ješina, 2008).

\section{Speciálně pedagogická centra}

Dětí se zdravotním postižením integrovaných $\mathrm{v}$ běžných školách neustále přibývá. Při integračním procesu významně pomáhají Speciálně pedagogické centra (SPC), jejichž zaměstnanci jsou většinou odborníci na všechny předměty kromě tělesné výchovy. Přispívají při odstraňová- 
ní bariér, zajištění podmínek pro výuku, konzultací s pedagogem, výrobě individuálních vzdělávacích plánů atd. $K$ tomuto však většinou nedochází v př́ípadě tělesné výchovy a je to pochopitelné. Tělesná výchova (TV) je specifickým předmětem s ohledem na cíle, náplň, bariéry, pomůcky a další.

Spolupráce SPC se školou při integraci žáka je bezesporu velice důležitá. Poukazuje na to i vysoký počet SPC v České republice. ÚIV uvádí v rejstř́ku školských zařízení 104 speciálně pedagogických center. Dle ÚIV měli všechna tyto centra ve školním v roce 2009/2010 ve své péči 55797 klientů se zdravotním postižením. Na každé centrum tak vychází průměrně 537 žáků se SVP. Toto číslo už je poměrně vysoké a poukazuje tak na vysokou využitelnost těchto zařízení.

SPC mají největší přehled o žácích se SVP a jejich začlenění do jednotlivých předmětů ve škole. Všeobecně se shodují, že TV je mezi posledními, kde se o integraci společně se školou snaží. Z výzkumného šetření Ješiny et al. (2011), kde bylo osloveno 42 SPC ze sedmi krajů, vyplývá, že všechny SPC si uvědomují smysluplnost zařazení žáků se SVP do pohybových aktivit. Většina pracovníků ze SPC $(61,9 \%)$ se domnívá, že má dostatek informací a možností pro co nejoptimálnější apojení žáků se SVP do školní tělesné výchovy.

Nejvíce překážek vidí pracovníci SPC v oblasti personální. Většinou asistenti mají určený počet hodin, který je daný na týden. Ve vyšších ročnících však tato časová dotace nedostačuje na počet hodin žáka se SVP. Předmětem, který se pak často u žáka vynechává, je některá z výchov. Nejčastěji je to však TV, která je nejvíce náročná na organizaci. Tato situace se pak musí řešit náhradními možnostmi, ale mnohem častěji je jednoduše zrušena.

SPC může být jedním z iniciátorů integrace do TV. Pokud SPC integraci do TV doporučí, přístup školy $\mathrm{k}$ této problematice se může změnit. SPC mohou být i v počáteční fázi prostředníkem mezi školou a rodiči. Pokud rodičům účast $\mathrm{v}$ TV $\mathrm{v}$ nějaké podobě doporučí, rodič může být ten, kdo bude usilovat o integraci dítěte do TV.

Jednou z možností řešení situace v současných SPC je vytvoření pozice pro dalšího pracovníka, který by byl odborníkem na oblast TV. 


\section{Spolupráce s dalšími kompetentními osobami}

Při samotné realizaci integrované školní TV je potřeba vzít v úvahu relevantní determinanty, které mají na samotný proces začleňování vliv.

Pro úspěšnou integrovanou TV se musíme zaměřit nejenom na typ a charakteristiku zdravotního postiženi žáka se SVP. Nejdůležitější jednotkou, která ovlivňuje celý integrační proces, je samotný žák se SVP, a především jeho přání a motivace. Je potřeba zvážit, zda integrace dítěte bude př́nosem pro něj a zda nebude negativně ovlivňovat průběh TV. Na integraci závisí i možnosti školy (personál, architektonické bariéry, pomůcky). Z dalších věcí, které je potřeba před samotnou integrací poznat, je osobnost ditěte a spolužáci. Velkou roli hrají i rodiče a pedagogové.

Rodiče mají jako zákonní zástupci nezastupitelnou roli v účasti žáků se SVP ve školní TV. Legislativní systém účasti nebo neúčasti v integrované formě vzdělávání, včetně školní TV, je přímo podmíněn přáním a rozhodnutím rodičů. Pokud se tento systém týká uvolnění ze školní TV, pak rodič je tím, kdo souhlasí nebo nesouhlasí s účastí žáka ve školní TV. Jak uvádí Dostál (2011), paradoxně rodiče jsou často těmi, kteří přímo vyžadují po lékařích uvolnění svých dětí z TV. Důležitou roli zde však sehrává i ředitel školy, který musí personálně a organizačně zajistit vzdělávání žáků se speciálními potřebami. Uvolnění od školní docházky a předmětů (nejčastěji TV) je na základě zákona 317/2008 Sb. (úplné znění zákona 561/2004) možné ze zdravotních nebo jiných závažných důvodů (viz $§ 50)$. V praxi jsme tedy často svědky uplatňování systému, který bývá označován jako „fenomén uvolnění ze školní TV“ na základě doporučení praktického lékaře pro děti a dorost nebo v oboru všeobecné praktické lékařství. Osobou, která uvolňuje žáka, je pak ředitel dané školy.

Pro účast žáka se SVP je nutné znát podrobnou diagnostiku zdravotního postižení a př́padné kontraindikace týkající se pohybových aktivit. Na základě lékařského a posléze i kinantropologického (diagnostika úrovně pohybových schopností a dovedností) vyšetření, by měl být připraven obsah školní TV s ohledem na specifika postižení, intenzitu zatížení apod. To, že žák nesmí s ohledem na zdravotní rizika realizo- 
vat některé pohybové aktivity, by nemělo být v žádném případě důvodem k jeho uvolnění z TV. Pokud není pro žáka vhodné, aby se účastnil tradiční školní TV, pak by mu měla být navržena účast ve zdravotní TV, př́padně s ohledem na typ školy, pohybová výchova, rehabilitační TV nebo mimoškolní léčebná TV. Dle Ješiny a Kudláčka (2009) by podklady od lékaře měly sloužit k úpravě IVP, řešení využití asistence, kompenzačních pomůcek, samotných realizovaných pohybových aktivit, naplánování variabilních forem, zvážení možností jednotlivých stupňů začlenění. Tyto úpravy jsou plně v kompetenci učitele TV, který by měl být na základě svého vysokoškolského vzdělání (nebo př́padně celoživotního vzdělání) připraven na vypracování IVP ve spolupráci se SPC.

Při pilotních šetřeních zaměřených na „fenomén uvolnění ze školní TV“ (Dostál, 2011) jsme zjistili především nekompetentnost lékařů určit, které pohybové aktivity by byly pro žáka vhodné vzhledem k charakteru jeho postižení. Lékaři vzhledem ke svým pracovním úkolům ani nejsou povinni vzdělávat se v těchto oblastech. To by mělo být úkolem pedagogických pracovníků. $Z$ toho důvodu se jako jediným možným východiskem ukázalo zpracování strukturovaného posudku, který je učiteli TV podkladem pro tvorbu IVP. Návrh struktury prezentujeme v tab. 1. Tyto anamnestické údaje musí být učiteli TV srozumitelné a v př́padě přesahu i do jiných předmětů (člověk a svět práce, hudební výchova, výtvarná výchova, dramatická výchova, případně další) by měl informovat další relevantní pedagogické zaměstnance školy. 
Tab. 1: Rámcový návrh struktury podkladi̊ pro lékařské pracovníky

\begin{tabular}{|c|c|c|c|}
\hline Jméno: & Školní rok: & Věk: & Autor posudku: \\
\hline \multicolumn{4}{|c|}{$\begin{array}{l}\text { Doporučené pohybové aktivity (zaškrtněte doporučené a př́ípadně } \\
\text { konkretizujte): }\end{array}$} \\
\hline$\square$ & \multicolumn{3}{|l|}{ Relaxační - } \\
\hline$\square$ & \multicolumn{3}{|l|}{ Aerobní cvičení - } \\
\hline$\square$ & \multicolumn{3}{|l|}{ Silové - } \\
\hline$\square$ & \multicolumn{3}{|c|}{ Vytrvalostní (cca nad 1500 m) - } \\
\hline \multicolumn{4}{|c|}{$\begin{array}{l}\text { Modifikované pohybové (sportovní) aktivity - upravená } \\
\text { pravidla, různé kompenzační pomůcky, lehčí míče, jiná intenzita } \\
\text { zatížení než ostatní hráči, změna lokomoce dle potřeb žáka (vozík, v } \\
\text { sedě, v leže, chůze apod.), atd. - }\end{array}$} \\
\hline$\square$ & \multicolumn{3}{|c|}{ Rehabilitační (včetně jógy, tai-chi, aj.) - } \\
\hline$\square$ & \multicolumn{3}{|l|}{ Strečink (protahování) - } \\
\hline$\square$ & \multicolumn{3}{|c|}{ Rozvoj jemné motoriky - } \\
\hline$\square$ & \multicolumn{3}{|c|}{ Rozvoj hrubé motoriky - } \\
\hline
\end{tabular}


Rozvíjení úrovně koordinačních schopností -

Rozvoj sebeobslužných činností -

Turistika -

- $\quad$ Krátké úseky (do $5 \mathrm{~km}$ )

- Dlouhé úseky (nad $5 \mathrm{~km})$

Cykloturistika -

- $\quad$ Krátké úseky (do $10 \mathrm{~km}$ )

- $\quad$ Dlouhé úseky (nad $10 \mathrm{~km})$

Sjezdové lyžování (včetně modifikovaného pasivního lyžování na monoski $\mathrm{s}$ intruktorem, př́padně lyžování s vodičem u žáků se zrakovým postižením) -

Běžecké lyžování -

- $\quad$ Krátké úseky (do $5 \mathrm{~km}$ )

- Dlouhé úseky (nad $5 \mathrm{~km})$

Aktivity ve vodním prostředí - plavání, aquaaerobic, potápění do $2 \mathrm{~m}$, hry ve vodě, aj. -

Další - 
Doporučení lékaře pro zařazení do různého typu aplikované tělesné výchovy (ATV) - zaškrtněte:

Integrovaná TV (na běžné ZŠ a SŠ)

TV (ATV) s nezbytnými úpravami obsahu a podmínek dle doporučených pohybových aktivit (na běžné ZŠ a SŠ i na škole zř́zené pro žáky se SVP)

$\square \quad$ Zdravotní TV

$\square \quad$ Pohybová výchova (pokud žák navštěvuje ZŠ speciální)

$\square \quad$ Rehabilitační TV (pokud žák navštěvuje ZŠ speciální)

Léčebná TV (jako náhrada za školní TV, pokud je to nejvhodnější typ dle charakteru postižení žáka)

Kontraindikace (doporučení k omezení) k pohybovým aktivitám:

Prognóza pro vývoj motoriky. Jaké jsou další plánované lékařské a zdravotnické intervence (rehabilitace, operace atd.):

Stanovisko zákonného zástupce (projevený zájem o zařazení žáka do školní TV) a potvrzení (podpisem), že byl seznámen s výše uvedenými informacemi:

Podpis lékaře: 
Podstatné je, aby všichni, kteří se na integraci ve školní TV podílejí, měli kladný postoj $\mathrm{k}$ celé problematice a byli vnitřně motivování. Klíčovou roli v tomto procesu sehrávají rodiče a pedagogové (nejvíce pak učitel TV). Pokud rodiče mají kladný vztah k pohybovým aktivitám a vědí o možnostech osob se zdravotním postižením zapojit se do sportu a TV, pak sami aktivně působí na účast svého dítěte ve školní TV. Pokud se s touto možností nesetkali, nemají žádné zkušenosti s pohybovými aktivitami u osob se zdravotním postižením, mohou se integrace obávat. Toto pak může být zásadní překážkou. Podobné je to i s učiteli TV. Je na nich velká zodpovědnost za dítě, a proto neznalost této problematiky může zapř́činit jejich negativní postoj. Proto je nutná informativní strategie, která zvýší povědomí rodičů o možnostech jejich dětí. Často objevujícím se problémem v integraci do TV, kde se rodiče mohou podílet na řešení, jsou sportovně kompenzační pomůcky a nepřítomnost asistentů. V naší praxi se setkáváme s tím, že pokud v integrované TV není přítomen asistent, je integrace složitější nebo v některých případech nemožná. Proto když rodiče chtějí, aby jejich dítě TV navštěvovalo, je možné, že si asistenta zajistí sami jen pro hodiny TV. V současné situaci, kdy je proškolených asistentů nedostatek, se stává, že rodič dítěte zaujme toto místo. Je otázkou, zda je to pro dítě dobré. Je potřeba, aby dítě mělo určitou volnost a pomalu se osamostatnilo. S ochranitelskými pudy rodičů toto může být problém. Uzlová (2010) tvrdí, že v roli asistentů se dobře osvědčují maminky po mateřské dovolené, které mají zkušenosti s výchovou vlastních dětí. Varianta, kdy funkci asistenta pedagoga zastává rodinný příslušník (většinou maminka nebo babička) začleněného žáka, je sporná. Mnozí rodinní příslušníci tuto praxi na základě vlastních zkušeností obhajují, odborníci se však častěji staví proti.

Nejdůležitější osobou (kromě samotného žáka) ve výchovně vzdělávacím procesuje je učitel (v našem případě učitel TV, včetně učitele TV na I. stupni základní školy). Má hlavní zodpovědnost za průběh hodiny, bezpečnost žáků a výsledky hodin. Proto když se rozhodne pro integraci žáka se SVP do TV, největší část prŕípravy je na něm. Důležité při integraci je, zda učitel má nějaké vzdělání v oblasti aplikovaných pohybových 
aktivit (včetně neformálního) nebo se již s integrací dříve setkal. Při integraci žáka se SVP by mělo dojít k určitým modifikacím a upravení podmínek. Ne však každý pedagog TV je přesvědčen, že je tohoto schopen. Ješina (2011a) navrhuje změny, které by se měly udělat ve vzdělávání budoucích pedagogů nebo pedagogických pracovníků. Všichni učitelé tělesné výchovy a odborníci vyučující tělesnou výchovu ve speciálních školách nebo institucích by měli získat odpovídající školení. Přiměřená podpora tělesné výchovy pro žáky se SVP by měla zahrnovat školení dalších pedagogických pracovníků (asistenti pedagoga) a programy s podporou vrstevníků (peer tutoring).

\section{ZÁVĚR}

Tělesná výchova na školách může výrazně dopomoci k pozitivnímu vztahu k pohybovým aktivitám a sportu. Dítě se může naučit nejen jak se správně hýbat, ale také zažít nenahraditelné pocity při překonávání samo sebe a při konfrontaci se spolužáky. Právě emocionální zážitky dávají tělesné výchově svou výjimečnost. Úspěšná integrace do TV je však hlavně o př́stupu lidí kolem žáka se zdravotním postižením a jejich pozitivním postoji i snaze.

\section{LITERATURA}

Ješina, O. (2011a). Kompetence učitelů aplikované tělesné výchovy. Tělesná kultura, Dostál, M. (2011). Zařazení žáka s tělesným postižením do školní tělesné výchovy (pilotni studie). Bakalářská práce, Univerzita Palackého v Olomouci, Fakulta tělesné kultury, Olomouc. 34 (2), 19-44.

Ješina, O., Bartoňová, R., Gebauer, S., Rybová, L., Kučera, M., \& Vyhlídal, T. (2011) Konzultant aplikovaných pohybových aktivit jako poradenský pracovník pro školní tělesnou výchovu. Česká kinantropologie, 15 (4), 95-106.

Ješina, O., \& Kudláček, M. (2009). Modifikace pohybových aktivit pro participaci dětí, žáků a studentů se zdravotním postižením v integrované školní tělesné výchově. Speciálni pedagogika, 19 (3), 227-237. 
Ješina, O., Kudláček, M., et al. (2011). Aplikovaná tělesná výchova. Olomouc: Univerzita Palackého v Olomouci.

Kudláček, M. (2008). Integrace žáků s tělesným postižením v kontextu školní tělesné výchovy. In M. Kudláček \& I. Machová (Eds.), Integrace - jiná cesta (pp. 11-19). Olomouc: Univerzita Palackého.

Kudláček, M., \& Ješina, O. (2008). Integrace žákůs tělesným postižením do školni tělesné výchovy. Olomouc: UP v Olomouc.

Kudláček, M., Ješina, O., \& Štěrbová, D. (2008). Integrace žáků s tělesným postižením v kontextu školní tělesné výchovy. Speciální pedagogika, 18 (3), 232-239.

Ministerstvo školství, mládeže a tělovýchovy (2005). Vyhláška č. 73/2005 Sb., o vzdělávání dětí a žákủ se speciálními vzdělávacími potřebami a dětí a žáki̊ mimořádně nadaných.

Parlament ČR. (2004). Zákon č. 561/2004 Sb., o předškolním, základním, středním, vyšším odborném a jiném vzdělávání.

Parlament ČR. (2004). Zákon č. 563/2004 Sb., o pedagogických pracovnících a o změně některých zákonů.

Parlament ČR. (2008). Zákon 317/2008 Sb., úplné znění zákona č. 561/2004 Sb., o předškolním, základním, středním, vyšším odborném a jiném vzdělávání (školský zákon).

Parlament ČR. (2011). Zákon 371/2011 Sb. o specifických zdravotních službách.

Ústav pro informace ve vzdělání (2011). Retrieved October 21, 2011, from http://toiler.uiv.cz/rocenka/rocenka.asp.

Uzlová, I. (2010). Asistence lidem s postižením a znevýhodněním. Praktický průvodce pro osobní a pedagogické asistenty. Praha: Portál.

\section{KONTAKT:}

Mgr. Radka Bartoňová, bartonova.apa@upol.cz 